\title{
ESSAY
}

\section{The Creation and Deconstruction of America's Inner City Criminals}

\author{
Eugene Hunter \\ Exchange for Change, US \\ exchangeforchange@gmail.com
}

In this internal account of prison life, the essay utilizes both prose and poetry to interrogate issues of incarceration, criminology, socioeconomics, and pedagogy. The work ultimately calls for a utilization of Paulo Freire's notion of the problem-posing concept of education as a preemptive measure to combat crime and reduce recidivism rates.

Keywords: Prison Life; Recidivism; Criminology; Pedagogy; Paulo Freire; Materialism; Criminal Justice Reform; Prison Reform

Before you read my essay, I want you to know I am not of academia. I am not some student at some university writing a thesis based on the experiences of others or on bold extrapolations of behavioral theory. I am writing and reasoning from a dingy prison cell in Florida. My roommate, whom I'm trying to ignore, is shirtless, writhing on the floor, riding a raging $\mathrm{K} 2$ high. We are two men, in one cell, doing two completely different things for the same reason. Abject hopelessness drives my roommate to smoke himself senseless. Abject hopelessness has stripped down my ego to allow me to objectively scrutinize my past actions and reasoning, even though it does not matter. My roommate and I have life sentences. So, whether I write and reform my mind or my roommate smokes $\mathrm{K} 2$ and destroys his, on this side of the fence, it does not matter.

By writing on this subject I am exposing the inner working of myself and people like me. People who made at best a half-conscious miscalculation to use illegal activity as means of economic survival and advancement. I am writing from the perspective of a black man born in Miami's Liberty City area. I have been incarcerated in the federal and state system for over 16 years without release. I have lived with more economic criminals than any criminologist will study. My experience decoding and analyzing my own tendencies as well as those of prisoners I've met renders me worthy to speak on the subject. Economic criminals are not born. They are conditioned by dilapidated institutions, lured, then condemned by poor choices. No one who has never committed a crime before wakes up one morning and suddenly says, "Today I will sell drugs," or "Today, I think I will rob a bank." Long before the first criminal act is ever committed they have been repeatedly conditioned to think, "having money makes me important," "money doesn't care where it comes from," "the ends justify the means," or "get rich or die trying."

In Pedagogy of the Oppressed, Paulo Freire defines the act of "filling" a student (the "receptacle") with an idea, knowledge, or school of thought as the "banking concept of education." In the above example, mass media, whether music videos or movies, act in the role of teacher, banking or conditioning the perspective economic criminal to grab hold of materialism. Unabated materialism is in the soul of all economic criminals. Surprisingly, this type of conditioning happens in some of the most unlikely places-inner city classrooms. Growing up I remember many times a teacher got up and asked the class, "What do you want to be when you grow up?" Young hands shot up and, like parrots, one student would answer "a fireman," another "a teacher," another "a CEO," and another "a painter." I remember a teacher saying, "You don't want to be a painter. They don't make much money." Of course, the student that said "a painter" changed his answer to "CEO."

I am not implying the conversation caused me or any other kid to become an economic criminal. What I am saying is this type of conversation was part of our indoctrination into get-rich-materialism, which is the core problem of the mentality of economic criminals. Applying Freire's concepts, this conversation (and many others like it) banked into my subconscious-"I live to serve a task." This conversation and many others 
like it conveyed to my subconscious, "passion does not matter," "money is the motive." As a kid, I did not realize this message, and neither did the teachers, but it is apparent.

In Pedagogy of the Oppressed Paulo Freire warns of the coercive effects of the banking concept of education. He states:

The more students work at storing the deposits [from the teacher] entrusted to them, the less they develop the critical consciousness, which would result from their intervention in the world as transformers of that world. The more they accept the passive role imposed on them, the more they tend simply to adopt to the world as it is and to the fragmented view of reality deposited in them (73).

I am no apologist for myself or economic criminals. Wrong is wrong. But what happens to young minds when they are banked by materialism on all sides? Abject materialism at school, at home, from the media. What happens to young minds when you're in the hood, everyone you know is poor or working poor, and the only people you know who have nice things are surviving off illicit gain? What happens when young minds are flooded with images of sex, drugs, and violence, where consequences of death and prison are commercialized caricatures of reality?

No one is forced to live a life of crime. However, I cannot escape the conclusion that society, whether intentionally or unintentionally, has set snares for a significant percentage of my demographic to fail, applying principles of free will and systemic decay to myself and the lives of others. I see a strange duality, a war of consciousness I cannot put into easy sentences. I offer instead a poem to explain my paradox:

Iron Zoo

We were elaborate, metallic parrots

Locked in on MTV cages.

We did what they told us to do.

We said what they taught us

To say.

Like electric lemurs in a digital inner city

Zoo with no fences.

We left blood splatter

Brain matter, footprints

Down the path of destruction.

With an I-don't-give-a-fuck-attitude,

We plunged head first

Off the zoo keeper's cliff.

To deconstruct the mentality of the inner city economic criminals we must as a society implement Freire's concepts of the problem-posing style of education, starting in elementary schools all the way up to higher learning and career training institutions. To reduce recidivism, the prison system must implement career training and higher learning outreach programs. It is obscene to incarcerate a person for decades, teach them nothing, offer them no means of betterment, then act surprised when the former inmate just robbed the Seven Eleven down the street.

\section{Competing Interests}

The author has no competing interests to declare.

\section{Reference}

Freire, Paulo. Pedagogy of the Oppressed. Trans. Myra Bergman Ramos. New York: Continuum, 2000. 
How to cite this article: Hunter, E 2019 The Creation and Deconstruction of America's Inner City Criminals. Anthurium, 15(2): 6, 1-3. DOI: https://doi.org/10.33596/anth.390

Published: 23 September 2019

Copyright: (c) 2019 The Author(s). This is an open-access article distributed under the terms of the Creative Commons Attribution 4.0 International License (CC-BY 4.0), which permits unrestricted use, distribution, and reproduction in any medium, provided the original author and source are credited. See http://creativecommons.org/licenses/by/4.0/. 